\title{
The rate of free amino acid disappearance from the rumen content
}

\author{
J. Kowalczyk \\ The Kielanowski Institute of Animal Physiology and Nutrition, Polish Academy of Sciences \\ 05-110 Jablonna, Poland
}

(Received 30 August 1993; accepted 21 February 1994)

\begin{abstract}
A mixture of free amino acids was incubated in vitro with rumen liquor or administered as either a single dose or continuous infusion into the rumen of sheep fitted with a simple rumen cannula and reentrant duodenal cannula. The rate of disappearance of amino acids from the incubated liquor was slow and varied for individual amino acids. The most rapidly disappearing amino acid was cysteine. Glycine, alanine, histidine and valine were decomposed more slowly reaching a level of degradation not exceeding $70 \%$ of their initial concentration after $24 \mathrm{~h}$ of incubation. Phenylatanine was not degraded during $24 \mathrm{~h}$ incubation.

In vivo, amino acids rapidly disappeared from the rumen at varied rates and only a small proportion of the amino acids introduced into the rumen reached the duodenum upon continuous infusion $(3.4 \%)$ or single injection $(7.4 \%)$. Most resistant to decomposition were thyrosine, cysteine and phenylalanine, while proline, methionine, asparagine, serine and glutamine were most readily decomposed.
\end{abstract}

KEY WORDS: sheep, rumen, duodenum, amino acid, deamination

\section{INTRODUCTION}

It is generally believed that free amino acids released in the rumen from feed protein are rapidly deaminated by bacterial deaminase. Such a conclusion is based on the low free amino acid concentration in rumen liquor (Wright and Hungate, 1967; Nugent and Mangan, 1981; Wallace and Cotta, 1988).

Lewis (1956) reported that the normal level of $\alpha$-amino nitrogen was in the range from 0.1 to $1.4 \mathrm{mg} / 100 \mathrm{ml}$ liquor in sheep fed on hay with casein, hay with dried grass or hay alone, but a value of $4.9 \mathrm{mg} / 100 \mathrm{ml}$ was found in the rumen of young bulls fed a urea/molasses diet (Kowalczyk et al., 1970; Ramirez and Kowalczyk, 1971). Some authors have reported that the rate of amino acid disappearance from the rumen liquor was relatively slow (Lewis and Emery, 1962; Emery, 1971; Isaacs and Owens, 1971).

The aim of the present study was to measure the rate of disappearance of individual free amino acids from rumen liquor in vitro and in vivo. 
MATERIAL AND METHODS

\section{Experiment in vitro}

Rumen liquor was obtained from 3 adult sheep fitted with rumen cannulas and fed a diet consisting of $80 \%$ meadow hay and $20 \%$ ground barley with a vitamin-mineral mixture. Portions of rumen liquor were filtered through a cheese cloth and pooled to obtain a homogeneous medium for incubation. Portions of $100 \mathrm{ml}$ were placed in incubation vessels and incubated alone or with a mixture of free amino acids. A mixture of $4 \mu \mathrm{mol}$ of each amino acid per $\mathrm{ml}$ of rumen liquor and hydrochloric acid or enzymatically hydrolyzed casein $(30-40 \mathrm{mg} / \mathrm{ml})$ were used as the source of free amino acids. Free amino acids were also added into the rumen liquor and boiled under a reflux column. Unsterilized rumen liquor with no addition of amino acids was also incubated as a control sample.

The medium was saturated with $\mathrm{CO}_{2}$ and the $\mathrm{pH}$ adjusted to 6.9 with $\mathrm{Na}_{2} \mathrm{CO}_{3}$. Incubations were carried out at $39^{\circ} \mathrm{C}$ with continuous bubbling of $\mathrm{CO}_{2}$. When the proper temperature, $\mathrm{pH}$ and $\mathrm{CO}_{2}$ saturation were attained, the respective aliquots of amino acids were pipetted into the incubation vessels. Five millilitre samples were taken at $0,0.5,1,2,4,6,8,12$ and $24 \mathrm{~h}$ of incubation and transferred to test tubes containing appropriate amount of sulphosalicylic acid solution so as to obtain a final concentration of $3 \%$ in order to precipitate the protein and stop the enzymatic decomposition of amino acids. The test tubes were left overnight at $4^{\circ} \mathrm{C}$, centrifuged and free amino acids concentrations were determined in the supernatant.

\section{Experiment in vivo}

The experiment was carried out with 8 sheep of $36 \mathrm{~kg}$ body weight fitted with simple cannulas into the rumen and reentrant cannulas into the duodenum. The animals were fed at 8.00 and $20.00 \mathrm{~h}$ with $400 \mathrm{~g}$ meadow hay and $100 \mathrm{~g}$ ground barley with a vitamin-mineral mixture. Solutions of $96 \mathrm{~g}$ hydrolyzed or unhydrolyzed casein were infused either continuously for $8 \mathrm{~h}$ or as a single injection into the rumen at the beginning of the morning feeding. All of the sheep were submitted to each treatment.

The samples of rumen liquor for measuring $\mathrm{pH}$ and amino acid concentration were withdrawn at 0,5 and $12 \mathrm{~h}$ after the infusion had started or the single injection had been administered. The amount of digesta entering the duodenum was measured for $12 \mathrm{~h}$ by the total collection method. Five per cent equivalents of digesta were taken for analysis at 2, 4, 8 and $12 \mathrm{~h}$.

Samples of the rumen liquor and duodenal digesta were spinned at $40,000 \mathrm{~g}$ and the supernatant stored in deep freeze until analyzed for total nitrogen 
content with the Kjeldahl method and free amino acids using a T-339 Automatic Amino Acids Analyzer.

\section{RESULTS}

\section{Experiment in vitro}

The amount of free amino acids in control rumen liquor with no addition of amino acids was negligible since it was below the detection limit of the method used. The recovery of amino acids from boiled rumen liquor after $24 \mathrm{~h}$ incubation was about $100 \%$. The pattern of in vitro disappearance of amino acids from the rumen liquor shown in Figure 1 as an average values was different for individual amino acids. The most rapidly disappearing amino acid was cysteine. Glycine, alanine, histidine and valine were decomposed more slowly, reaching a level of degradation not exceeding $70 \%$ of their initial amount after $24 \mathrm{~h}$ of incubation. Phenylalanine was not decomposed but, surprisingly, its amount even increased during incubation.

\section{Experinemt in vivo}

The pattern of ammonia concentration in the rumen liquor differed among treatments. Its concentration was similar in all groups before introduction of amino acids or casein into the rumen, but increased systematically during $12 \mathrm{~h}$ continuous infusion, more than when unhydrolyzed casein was given. After a single injection of amino acids or casein, the ammonia level increased about 5-fold with amino acids, and 3.5-fold with unhydrolyzed casein at $5 \mathrm{~h}$ post administration. Thereafter it decreased, with the lowest values found in the group receiving hydrolyzed casein (Table 1).

The $\mathrm{pH}$ of the rumen liquor was similar in all groups of animals at time 0 , reaching average values of 6.71 and 6.25 at $5 \mathrm{~h}$; after $12 \mathrm{~h}$ of continuous infusion the $\mathrm{pH}$ increased to about 6.16 and reached 6.53 after a single injection was given (Table 1).

The amount of crude protein entering the duodenum during $12 \mathrm{~h}$ digesta collection was less when hydrolyzed casein was given with continuous or single method than when unhydrolyzed casein was introduced and also less when hydrolyzed or unhydrolyzed casein was given by continuous method than when single injection was applied (Table 1).

The concentration of individual amino acids in the rumen liquor (Table 2) was very low in all of the animals at time 0 and after 5 and $12 \mathrm{~h}$ in animals given a single injection of hydrolyzed or unhydrolyzed casein or continuous infusion of unhydrolyzed casein. The exception was phenylalanine whose concentration. was 
TABLE 1

Ammonia concentration, $\mathrm{pH}$ values in the rumen liquor and crude protein amount entering duodenum after administering of casein into the rumen

\begin{tabular}{|c|c|c|c|c|}
\hline \multirow{2}{*}{$\begin{array}{c}\text { Treatment } \\
\text { Sampling time, } \mathrm{h}\end{array}$} & \multicolumn{2}{|c|}{ Continuous of casein } & \multicolumn{2}{|c|}{ Single injection of casein } \\
\hline & Hydrolyzed & Unhydrolyzed & Hydrolyzed & Unhydrolyzed \\
\hline \multicolumn{5}{|c|}{ Ammonia concentration, $\mathrm{mg} / 100 \mathrm{ml}$} \\
\hline 0 & 20.2 & 22.7 & 21.5 & 20.5 \\
\hline 5 & 42.7 & 35.7 & 106.0 & 77.2 \\
\hline 12 & 62.1 & 56.7 & 51.2 & 57.8 \\
\hline \multicolumn{5}{|c|}{$\mathrm{pH}$ - values } \\
\hline 0 & 6.78 & 6.64 & 6.68 & 6.74 \\
\hline 5 & 6.23 & 6.24 & 6.26 & 6.26 \\
\hline 12 & 6.14 & 6.18 & 6.51 & 6.56 \\
\hline \multicolumn{5}{|c|}{ Amount of crude protein entering duodenum, $\mathrm{g}$} \\
\hline $0-12$ & 40.4 & 47.4 & 51.2 & 60.8 \\
\hline
\end{tabular}

TABLE 2

Free amino acid concentration in the rumen liquor after introducing into the rumen hydrolyzed or unhydrolyzed casein as continuous or as a single injection, $\mathrm{mg} / 100 \mathrm{ml}$

\begin{tabular}{|c|c|c|c|c|c|c|c|c|c|c|c|c|}
\hline \multirow{3}{*}{$\begin{array}{l}\text { Treatment } \\
\text { Amino acid }\end{array}$} & \multicolumn{6}{|c|}{ Continuous infusion of casein } & \multicolumn{6}{|c|}{ Single injection of casein } \\
\hline & \multicolumn{3}{|c|}{ Hydrolyzed } & \multicolumn{3}{|c|}{ Unhydrolyzed } & \multicolumn{3}{|c|}{ Hydrolyzed } & \multicolumn{3}{|c|}{ Unhydrolyzed } \\
\hline & $0 \mathrm{~h}$ & $5 \mathrm{~h}$ & $12 \mathrm{~h}$ & $0 \mathrm{~h}$ & $5 \mathrm{~h}$ & $12 \mathrm{~h}$ & $0 \mathrm{~h}$ & $5 \mathrm{~h}$ & $12 \mathrm{~h}$ & $0 \mathrm{~h}$ & $5 \mathrm{~h}$ & $12 \mathrm{~h}$ \\
\hline Cys & 0.7 & 3.4 & 3.9 & 1.3 & 4.1 & 5.4 & 1.0 & 1.2 & 1.2 & 1.0 & 11.1 & 1.4 \\
\hline Asp & 0.4 & 19.4 & 37.6 & 0.5 & 0.8 & 1.1 & 0.7 & 0.8 & 0.8 & 0.7 & 2.0 & 0.7 \\
\hline Thr & 0.0 & 19.3 & 40.0 & 0.0 & 0.3 & 0.3 & 0.0 & 1.0 & 0.1 & 0.6 & 0.3 & 0.1 \\
\hline Ser & 0.0 & 22.1 & 29.4 & 0.0 & 0.3 & 0.6 & 0.0 & 0.2 & 0.2 & 0.1 & 0.8 & 0.1 \\
\hline Glu & 1.0 & 121.9 & 156.6 & 1.0 & 1.4 & 2.1 & 0.8 & 2.3 & 1.9 & 1.4 & 2.3 & 1.8 \\
\hline Pro & 0.0 & 56.5 & 115.5 & 0.0 & 0.4 & 0.1 & 0.0 & 0.3 & 0.2 & 0.0 & 0.2 & 0.1 \\
\hline Gly & 0.1 & 7.7 & 13.0 & 0.1 & 1.2 & 0.3 & 0.1 & 0.5 & 0.2 & 0.2 & 0.2 & 0.1 \\
\hline Ala & 0.2 & 17.5 & 23.5 & 0.1 & 0.3 & 0.7 & 0.1 & 2.0 & 0.5 & 0.2 & 0.5 & 0.3 \\
\hline Val & 0.0 & 30.3 & 50.0 & 0.1 & 1.0 & 0.5 & 0.1 & 6.9 & 0.2 & 0.2 & 0.5 & 1.0 \\
\hline Met & 0.0 & 8.1 & 14.1 & 0.0 & 0.1 & 0.1 & 0.0 & 1.8 & 0.0 & 0.0 & 0.2 & 0.1 \\
\hline Ile & 0.0 & 15.8 & 27.2 & 0.0 & 0.1 & 0.1 & 0.1 & 1.1 & 0.0 & 0.0 & 0.1 & 0.0 \\
\hline Leu & 0.0 & 24.3 & 37.9 & 0.0 & 0.5 & 0.5 & 0.0 & 1.1 & 0.0 & 0.0 & 0.1 & 0.0 \\
\hline Tyr & 0.0 & 8.1 & 5.9 & 0.1 & 1.3 & 1.5 & 0.0 & 0.2 & 0.5 & 0.3 & 2.9 & 0.1 \\
\hline Phe & 0.2 & 21.2 & 32.9 & 0.2 & 2.8 & 3.4 & 0.0 & 72.3 & 0.4 & 0.1 & 20.7 & 0.2 \\
\hline His & 1.0 & 16.7 & 26.2 & 0.4 & 1.5 & 1.9 & 0.4 & 4.3 & 1.0 & 0.6 & 1.6 & 0.5 \\
\hline Lys & 0.3 & 40.0 & 59.6 & 0.3 & 0.9 & 1.1 & 0.3 & 8.4 & 0.4 & 0.3 & 0.9 & 0.4 \\
\hline Arg & 0.0 & 6.5 & 18.8 & 0.0 & 0.0 & 0.2 & 0.0 & 0.2 & 0.0 & 0.0 & 0.0 & 0.0 \\
\hline Total AA & 3.9 & 438.8 & 688.1 & 4.1 & 17.0 & 19.9 & 3.7 & 104.6 & 7.6 & 5.7 & 44.4 & 6.9 \\
\hline
\end{tabular}



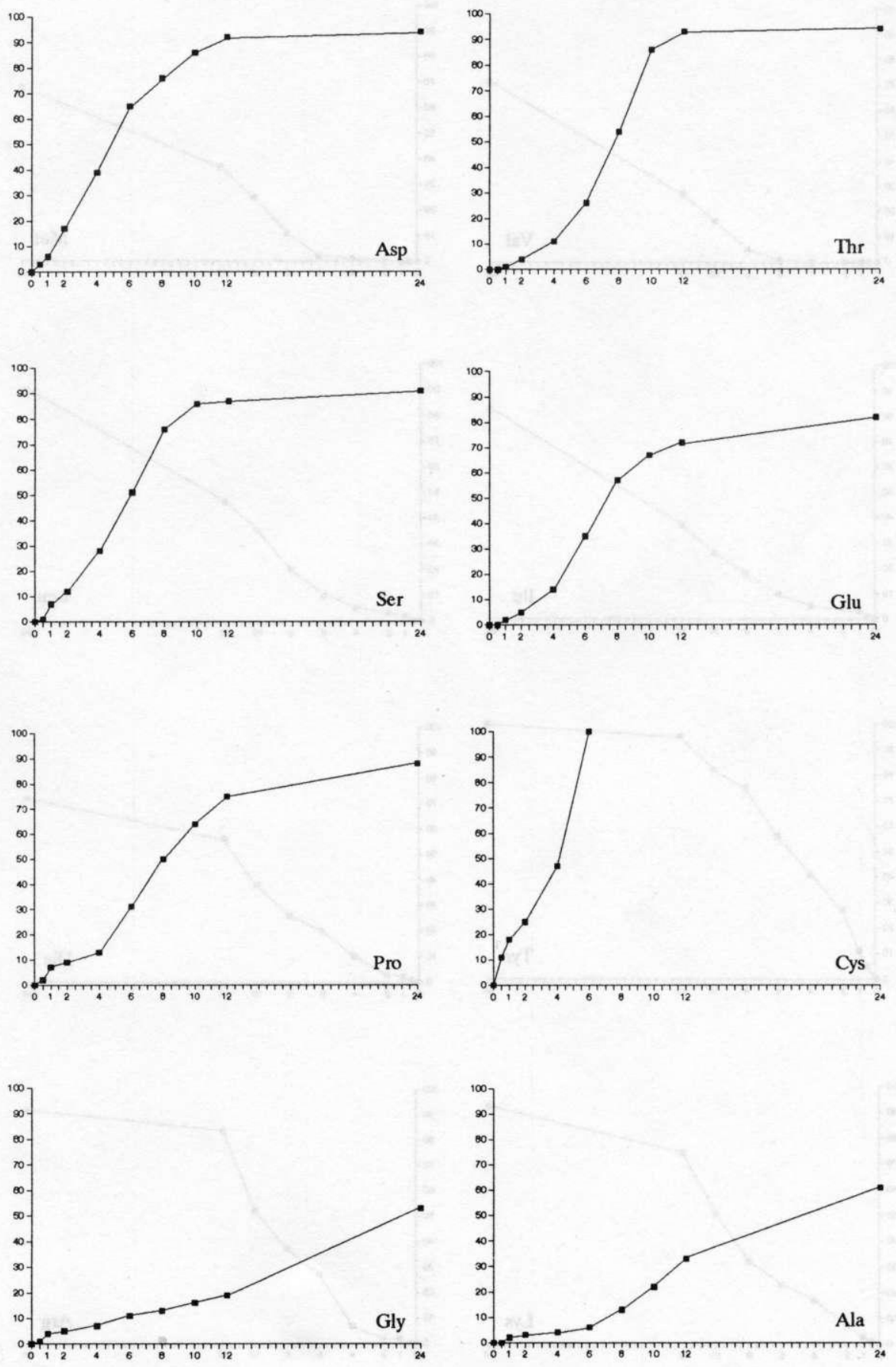

Fig. 1. Disappearance of free amino acids from the rumen liquor in vitro, $\%$ of initial amount 

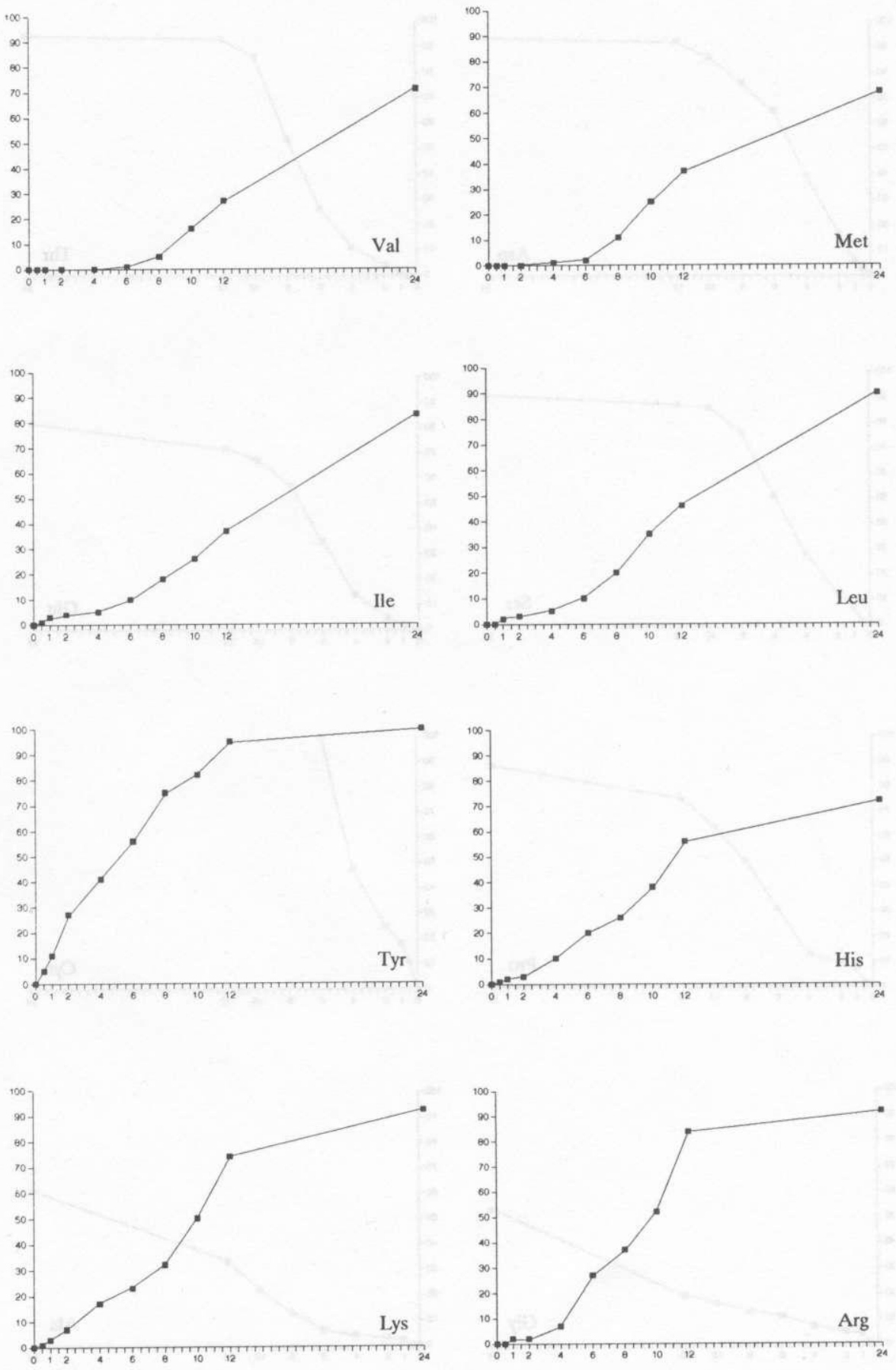

Fig. 1. Disappearance of free amino acids from the rumen liquor in vitro, $\%$ of initial amount 
72.3 and $20.7 \mathrm{mg} / 100 \mathrm{ml}$ in animals given single injections of hydrolyzed or unhydrolyzed casein, respectively.

The level of amino acids in the rumen liquor during continuous infusion of hydrolyzed casein increased singnificantly with time, reaching a total value of 438.8 and $688.1 \mathrm{mg} / 100 \mathrm{ml}$ after 5 and $12 \mathrm{~h}$, respectively.

The amounts of free amino acids administered to the rumen with hydrolyzed casein in a single dose or continuous infusion were equal (Table 3 ). The content of free amino acids in unhydrolyzed casein was very low and their amount introduced with casein into the rumen could be neglected.

More free amino acids were found in digesta entering the duodenum during the $12 \mathrm{~h}$ period of collection in sheep given a single injection of hydrolyzed casein than during continuous infusion, reaching proportions of 6.8 and 3.5 per cent of the total free amino acids introduced into the rumen, respectively. However, the recovery of individual amino acids introduced into the rumen from the duodenum differed markedly ranging from 1 to 20 per cent on continuous infusion and from 0 to 33 per cent on single injection. The highest recovery was for proline, asparagine, arginine, serine, methionine and glutamine. The concentration of free amino acids in the duodenal digesta after a single injection was highest in the first two hours and then decreased with time. The amount of free amino acids entering the duodenum during continuous infusion was low at the beginning of infusion and increased with time (Table 3).

The amount of free amino acids in digesta entering the duodenum of sheep receiving unhydrolyzed casein was markedly lower than in sheep receiving hydrolyzed casein, particularly after single injection: 45 and 24 per cent for continuous and single treatment, respectively (Table 3 ). Changes in the amount of free amino acids with time after introducing unhydrolyzed casein into the rumen were less pronounced than after hydrolyzed casein.

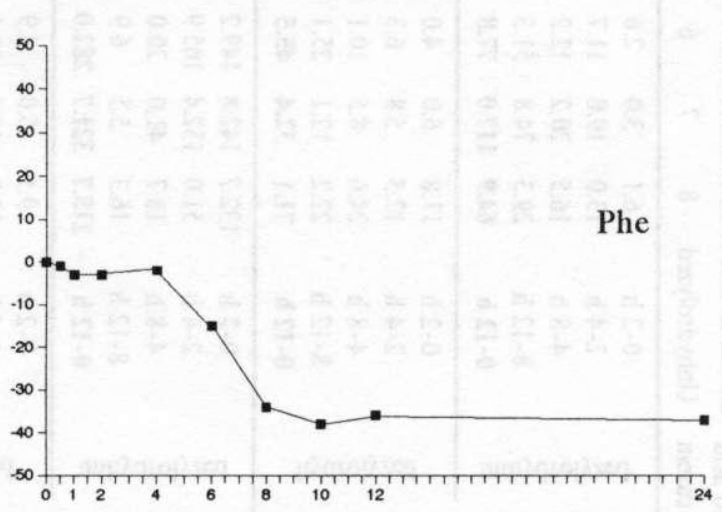

Fig. 1. Disappearance of free amino acids from the rumen liquor in vitro, $\%$ of initial amount 
TABLE 3

The amount of free amino acids introduced into the rumen with hydrolyzed or unhydrolyzed casein and thier amount entering duodenum during digesta collection time, mg

\begin{tabular}{|c|c|c|c|c|c|c|c|c|c|c|c|c|c|c|c|c|c|c|c|c|}
\hline & & mino acid & Asp & Thr & Ser & Glu & Pro & Cys & Gly & $\mathrm{Ala}$ & $\mathrm{Val}$ & Met & Ile & Leu & Tyr & Phe & His & Lys & Arg & Total \\
\hline \multirow{2}{*}{\multicolumn{2}{|c|}{$\begin{array}{l}\text { Introduced free } \\
\text { amino acid } \\
\text { with casein }\end{array}$}} & $y d$ & 6574 & 3757 & 4770 & 1810 & 12591 & 446 & 1646 & 282 & 442 & 1660 & 2436 & 4503 & 686 & 2538 & 3142 & 78 & 2975 & 84262 \\
\hline & & Unhyd & 8 & 7 & 6 & 14 & 0 & 9 & 2 & 18 & 14 & 3 & 6 & 17 & 16 & 9 & 10 & 20 & 7 & 166 \\
\hline \multirow{10}{*}{ 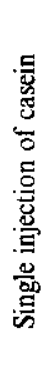 } & \multirow{5}{*}{ 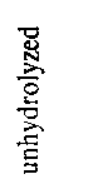 } & 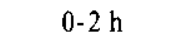 & 6. & 3.0 & 2.6 & 1 & 0 & 11.6 & 0 & 1. & 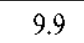 & I & t & 4 & 9 & 30.8 & 5 & & 0.5 & 152.5 \\
\hline & & $2 \cdot 4$ & 13.0 & 19.0 & 11.7 & 87.7 & 0.0 & 15.8 & 10.5 & 21.3 & 32.6 & 0 & 12.3 & 23.3 & 20.5 & 61.5 & 56.8 & 34 & 5.0 & 432.1 \\
\hline & & $4-8$ & 16.5 & 20.2 & 12.2 & 126.8 & 46.3 & 26.0 & 13.9 & 38.8 & 8 & 9 & 25.3 & 4 & 4 & 3 & 71.5 & 5 & 3 & 720.2 \\
\hline & & 8 & 29.3 & 74.8 & 51.3 & 436.0 & 59.9 & 36.9 & 30.9 & 53.8 & 161.4 & 23.3 & 61.9 & 93.4 & 60.4 & 53.6 & 132.2 & 140.2 & 3.4 & 1612.7 \\
\hline & & $0-12 h$ & 64.9 & 117.0 & 77.8 & 667.0 & 106.2 & 90.3 & 63.4 & 121.8 & 287.7 & 41.2 & 100.8 & 162.1 & 134.9 & 322.2 & 291.0 & 238.0 & 31.2 & 2917.5 \\
\hline & \multirow{5}{*}{ 芯 } & & & 6.0 & 4 & & & & 4.9 & & & & 2.7 & 8.1 & 10 & 4 & 36.4 & & .5 & 147.7 \\
\hline & & & & 5. & 6 & & & 2 & 6 & 1 & $\gamma$ & & 4. & I & 2 & 9 & 42.1 & 11 & 9 & 249.8 \\
\hline & & $4-8$ & 24.6 & 8.5 & 10.1 & 38 & 0 & 50.0 & 9.4 & 16.6 & 12 & 2.9 & 7.6 & 14.0 & 65. & 56.5 & 80.0 & 30 & 7.3 & 434.7 \\
\hline & & $2 \mathrm{~b}$ & 22.2 & 12.1 & 5.1 & 34 & 0 & 46.3 & 13.0 & 17.8 & 16 & 3.1 & 9.6 & 15.6 & 69.5 & 54.1 & 73.0 & 49.1 & 7.7 & 469.2 \\
\hline & & $12 \mathrm{~h}$ & 71.1 & 32.4 & 45.5 & 95.9 & 0.0 & 132.6 & 33.7 & 51.6 & 43.5 & 9.4 & 24.7 & 51.0 & 175.6 & 185.9 & 231.5 & 96.6 & 20.4 & 1301.4 \\
\hline \multirow{10}{*}{ 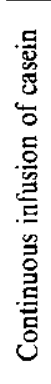 } & \multirow{5}{*}{ 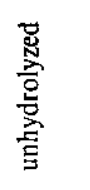 } & & & & & & & & & & & & 99.4 & & 9 & .3 & 3 & & 62.7 & 2495.4 \\
\hline & & 2 & 51.0 & 132.4 & 05.9 & 5. & & 17.3 & 40 & 85.4 & 1 & 40.0 & 85.5 & 129.0 & 56.2 & 211.2 & 108.6 & 2 & 26.7 & 2051.8 \\
\hline & & $4.8 \mathrm{~h}$ & 18.7 & 41.0 & 20.0 & 143 & & 23.6 & 18 & 25.4 & 73 & 6 & 22.4 & 37.7 & 37.4 & 227.7 & 80.1 & 102.3 & 7.7 & 885.4 \\
\hline & & . & 16.3 & 5.5 & 6.9 & 51.3 & 0.0 & 21.2 & 13.1 & 8.4 & 11.4 & 0.8 & 4.5 & 14.9 & 36.2 & 18.9 & 62.2 & 17.4 & 7.6 & 296.6 \\
\hline & & $0-12$ b & 218.7 & 321.7 & 282.0 & 1396.4 & 0.0 & 86.6 & 128.0 & 220.9 & 463.8 & 98.3 & 211.6 & 350.9 & 223.1 & 557.1 & 394.2 & 671.2 & 104.7 & 5729.2 \\
\hline & \multirow{5}{*}{$\frac{\mathbb{2}}{\frac{\mathbb{N}}{2}}$} & & & & & & & & & & & & & & & & & & 1.3 & 217.1 \\
\hline & & & 23 & 10.6 & 10 & & & 9 & & 1 & 18 & 5 & 8 & 37. & 60 & 45.9 & 74.3 & & . & 463.5 \\
\hline & & & 10. & 13.1 & 14. & 23 & & 42 & 10 & 26 & 23 & 5 & 15. & 36 & 53 & 2.5 & 56.8 & 16 & 6.4 & 364.9 \\
\hline & & $12 \mathrm{~h}$ & 22.5 & 10.3 & 11.4 & 35 & 0. & 43.6 & 14 & 17. & 13 & 3.8 & 8.2 & 22.8 & 51.7 & 0.0 & 79.2 & 18.7 & 2.4 & 355.9 \\
\hline & & $12 \mathrm{~h}$ & 71.6 & 39.0 & 1.3 & 89.5 & 0.0 & 216.4 & 38.5 & 67.0 & 63.2 & 15.6 & 35.2 & 108.2 & 192.7 & 80.5 & 247.9 & 82.1 & 12.7 & 1401.4 \\
\hline
\end{tabular}




\section{DISCUSSION}

El-Shazly (1952) was one of the first who reported that degradation of protein by rumen microorganisms resulted in decomposition of amino acids. Sirotnak et al. (1953) investigated the metabolism of amino acids by a mixed suspensions of rumen microorganisms. Of twenty two amino acids tested, aspartic and glutamic acids, serine, arginine, cysteine and cystine were found to be attacked at optimum pH 6.9. Lewis and Emery (1962) divided individual amino acids into 3 groups with regard to their relative rate of deamination during incubation. Serine, cysteine, threonine and arginine were attacked most completely, followed by glutamic acid, phenylalanine, lysine and cystine and those attacked least were tryptophan, methionine, alanine, valine, isoleucine, histidine, glycine and proline. The $\mathrm{D}$ or $\mathrm{L}$ forms of serine and tryptophan were decomposed at the same relative rates, whereas $D$ isomers of aspartic acid, lysine, threonine and phenylalanine were not attacked. Portugal and Sutherland (1966) showed that ${ }^{14} \mathrm{C}$ labelled glutamic acid was rapidly decomposed and only a non significant percentage of it was incorporated into bacterial protein.

Isaacs and Owens (1971) demonstrated that aspartic acid, glutamate and arginine were extensively decomposed - up to $90 \%$, phenolic amino acids were reduced under the same conditions by $50 \%$ but valine, leucine, isoleucine, methionine, alanine and glycine appeared to be relatively stable toward microbial action. Chalmers and Huges (1969) observed that glycine produced no increase in ruminal ammonia. Prins et al. (1979) reported that glutamate, proline, aspartate, serine and alanine were rapidly deaminated followed by arginine, phenylalanine, leucine, threonine, glycine, isoleucine which were decomposed more slowly and methionine, lysine and histidine were relatively most resistant to microbial attack. One of the reason for slow degradation of free amino acids in the rumen liquor could be that anaerobic bacteria preferentially take up peptides instead of amino acids or are even unable to utilize free amino acids directly (Prins, 1977; Wallace and Cotta, 1988).

From the present in vitro experiment it can be seen that all amino acids were relatively slowly decomposed and that disappearance was complete after 6 to 24 , or even more, hours of incubation with a characteristic lag time for the start of decomposition (Figure 1). The reason for this lag is unsure; a possible explanation is that the conditions of incubation should be adapted to in vitro activity after introducing amino acids into the medium.

The rates and extent of disappearance of free amino acids from incubates, as reported by various authors were changeable in different experiments and difficult to compare and interpret. The reasons for this are thought to lie in the different experimental conditions, proportion and concentration of individual amino acids, type of donor animals and their feeding regimen, rumen microflora 
compartition, incubation procedure etc. (Prins et al., 1979; Wallace and Cota, 1988). On analyzing the slow rate of disappearance of amino acids found in our experiment and the results of the in vitro experiments cited above, one could conclude that, of the free amino acids introduced into the rumen with the ration, a substantial proportion of them could avoid deamination in the rumen, be transported with digesta into the duodenum and be absorbed from the small intestine. However, that was not confirmed in the in vivo experiment.

The amount of total protein reaching the duodenum in the experiment in vivo was less than administered into the rumen, pointing to intensive decomposition of amino acids and absorption of nitrogen from the rumen. This effect was well pronounced when hydrolyzed casein was introduced or continuous infusion applied.

The proportion of free amino acids reaching the duodenum with digesta was calculated from the results given in Table 3 ; it amounted to only about $6.8 \%$ on single injection and to about $3.4 \%$ on continuous infusion of free amino acids introduced into the rumen. This clearly demonstrates that major part of the free amino acids present in the rumen were decomposed there and only a small proportion of them reached the duodenum. Free amino acids were also found in duodenal digesta of sheep given unhydrolyzed casein, but in relatively small amounts. They could have derived from protein hydrolysis in the abomasum.

The rate of disappearance of individual amino acids from the rumen varied. Thyrosine, cysteine and phenylalanine were found to be the most resistant to rumen degradation and about 28,20 and $17 \%$, respectively, of the amount administered to the rumen was recovered in the duodenum. Only $11 \%$ of histidine did not undergo decomposition, $9 \%$ valine and about $6 \%$ isoleucine, lysine, alanine, glycine, leucine and threonine; from 5.3 to $0.4 \%$ glutamine, serine, asparagine, methionine and proline was recovered in duodenal digesta. These results are convincing evidence that in order to avoid decomposition of amino acids introduced into the rumen effective protection from rumen degradation is essential.

\section{CONCLUSIONS}

The rate of disappearance of free amino acids incubated with rumen liquor in vitro or administered into the rumen was different for individual amino acids.

Amino acids disappeared in the rumen in vivo faster than when incubated with rumen liquor in vitro. Only a small proportion of amino acids administered into the rumen reached the duodenum on continuous infusion $(3.4 \%)$ or after a single injection $(7.4 \%)$. To cover the deficiency in the ration of a limiting amino acid for 
a ruminant, an amino acid efficiently protected from rumen degradation should be used.

Most resistant to decomposition in the rumen were: thyrosine, cysteine and phenylalanine, the least: glutamine, serine, asparagine, methionine and proline.

\section{REFERENCES}

Allison M.J., 1970. Nitrogen metabolism of ruminal micro-organisms. In: A.T. Philipson (Editor), Physiology of Digestion and Metabolism in the Ruminant. Oriel Press, Newcastle-upon-Tyne, pp. $456-472$.

Chalmers M.I., Hughes A.D., 1969. Single amino acids as non-protein nitrogen sources for adult sheep. Proc. Nutr. Soc. 28, 34A-35A

Chalupa W., 1976. Degradation of amino acids by mixed rumen microbial population. J.Anim. Sci. $43,828-834$

Cottle D.J., Welle W., 1989. Degradation and outflow of amino acids from the rumen of sheep. Br. J. Nutr. 61, 397-408

El-Shazly K., 1952. Degradation of protein in the rumen of sheep. 1. Some volatile fatty acids, including branched chain isomers, found in vivo. Biochem. J. 51, 640-653

Emery R.S., 1971, Disappearance of methionine from rumen. J. Dairy Sci. 54, 1090-1091

Isaacs J., Owens F.N., 1971. ${ }^{14} \mathrm{C}$ uptake by rumen microbes from urea and $\mathrm{NaHCO}_{3}$. J. Anim. Sci. 33, 287-288

Kowalczyk J., Ramirez. A., Geerken C.M., 1970. Nitrogen and carbohydrate metabolism in the rumen and duodenum of young bulls given diet based on molasses/urea. Rev. cubana Cienc. Agric. 4, 187-193

Lewis D., 1955. Amino acid metabolism in the rumen of the sheep. Br. J. Nutr. 61, 397-408

Lewis T.R., Emery R.S., 1962. Relative deamination rates of amino acids by rumen microorganisms. J. Dairy Sci. 45, 765-768

Nugent J.H.A., Mangan J.L., 1981. Characteristics of the rumen proteolysis of fraction I (18S) leaf protein from lucerne (Medicago sativa L.). Br. J. Nutr. 46, 39-58

Portugal A.V., Sutherland T.M., 1966. Metabolism of glutamic and aspartic acid in whole rumen contents. Nature 209, 510-511

Prins R.A., van Hal-Van Gestel J.C., Counotte G.H.M., 1979. Degradation of amino acids and peptides by mixed rumen micro-organisms. Z. Tierphysiol. Tiernähr. Futtermittelk. 42, 333-339

Prins R.A., 1977. Biochemical activity of gut micro-organisms. In: R.T.J. Clarke T. Bauchop (Editors), Microbial Ecology of the Gut.: Academic Press, London, pp. 73-183,

Ramirez A., Kowalczyk J., 1971. Synthesis of microbial protein in young bulls fed a protein-free diet based on molasses urea. Rev. cubana Cienc. Agric. 5, 21-26

Sirotnak F.M., Doetsch R.N., Brown R.E., Shaw J.C., 1953. Amino acid metabolism of bovine rumen bacteria. J. Dairy Sci. 36, 1117-1123

Wallace R.J., Cotta M.A., 1988. Metabolism of nitrogen-containing compounds. In: P.N. Hobson (Editor), The Rumen Microbial Ecosystem. Elsevier, New York, pp. 217-249

Wright D.E., 1967. Metabolism of peptides by rumen microorganisms. Appl. Microbiol. 15, 148-151

Wright D.E., Hungate R.E., 1967. Amino acid concentration in the rumen fluid. Appl. Microbiol. 15, 148-151 


\section{STRESZCZENIE}

Tempo rozkładu wolnych aminokwasów w treści żwacza owiec

Mieszaninę wolnych aminokwasów inkubowano in vitro z płynem żwaczowym lub podawano do żwacza owiec z przetoką do żwacza i mostkową przetoką dwunastnicy jednorazowo bądź metodą infuzji ciągłej. Tempo rozkładu aminokwasów w warunkach in vitro było stosunkowo powolne i różne dla poszczególnych aminokwasów. Najszybciej rozkładana była cysteina. Glicyna, alanina, histydyna i walina były rozkładane najwolniej osiągając poziom degradacji nie przewyższający $70 \%$ początkowego stężenia po 24 godz. inkubacji, a fenyloalanina nie uległa rozkładowi.

Aminokwasy podane do żwacza $\mathrm{w}$ doświadczeniu in vivo znikały ze żwacza stosunkowo szybko i zaledwie $3.4 \%$ podanej ich ilości przechodziło do dwunastnicy po podaniu metodą infuzji ciągłej, a $7.4 \%$ po jednorazowym podaniu do żwacza. Najwolniej rokładane były w żwaczu treonina, cysteina i fenyloalanina, a najszybciej prolina, metionina, asparagina, seryna i glutamina. 